\title{
Emergence of Rohingya Refugee: Present Situation and Future Impact on Local Peoples of Cox's Bazar in Bangladesh
}

\section{| Anwar Hossain Choudhury |}

\author{
Associate Professor \\ Departement of Sociology, \\ University of Chittagong, \\ Chattogram, Bangladesh \\ anwar.socio@cu.ac.bd
}

\begin{abstract}
Rohingya crisis is not a newly emerged problem in Bangladesh. Almost two and half years ago, it has been emerged as a great problem in Bangladesh, because of the quantity of Rohingya refugees. The main objective of the study is to understand the present and future situation of Rohingya refugee at cox's bazaar in Bangladesh and its impact on local people of cox's bazar. That will include social strains, political impact, security challenges. Economic effects, environmental destruction etc. The study is based on primary data will be collected from Rohingya refugee from Teknaf Upazila of Cox's Bazar in Bangladesh. Cox's bazar to find out the present situation and future impact for emerging Rohingya refugee on local people of cox's bazar. Which could help to identify the problems of Rohingya refugee for Bangladesh context.

KEYWORDS

Rohingya; refugee; crisis; socio-economic problem; emergence, local people.
\end{abstract}

\section{INTRODUCTION}

It has been nearly two years since the latest influx of the Rohingya people after they were forcibly driven out of Myanmar and into Bangladesh. Since the influx in August 2017, coupled with the host community and refugees from past influxes, the crisis affected population is now almost 1.5 million in Cox's Bazar, creating massive pressure on the already damaged environment of Cox's Bazar, Bangladesh (Ahmed, I. 2010). Over the period, the problem has been treated as one of emergency humanitarian assistance but now the government and international agencies are started to think on the long-term impact of looking after the Rohingyas in the camps as well as trying to let them return to Myanmar or probable relocation. But, all the efforts have been found to fail to either return them to Myanmar or other places. The situation is now critical, even NGO's are trying to keep them in Cox's Bazar.

However, the Government is trying to find a permanent solution with international enforcement (Alam, K. 2017). Foreign Secretary Shahidul Haque said in the UN Security Council meeting, "I regret to inform the council that Bangladesh would no longer be in a position to accommodate more people from Myanmar." He also urged the UNSC to take a decisive action to create a conducive atmosphere in Rakhine for Rohingy are patriation (Aljazeera. 2018). In regard to infectious diseases, the camp already got outbreak of measles, rota viral diarrhoea and cholera (Anand, J. 1978). In a recent report published by Cox's Bazar news on 9 March 2019, about three hundred nineteen people are already infected with Human Immunodeficiency Virus (HIV) where the number of females is higher than males. According to the World Health Organization (WHO), two female and one man died of HIV on February 2019. There are reports that, the female is being involved in the sex works in the hotels and motels, thereby spreading the deadly HIV and sexually transmitted disease 
throughout the country. The presence of the Rohingya is one of the biggest health threats in Bangladesh (www.thedailystart.net/rohingya-crisis). The United Nations Development program (UNDP) has identified key risks or indicators associated with this biggest influx. These are air quality, acoustic environment, ground water, surface water, soils and terrain, vegetation, wildlife, aquatic biology, forestry, human health, gender-based issues, land-use and waste management (Ahmed, I. 2010). The government of the people's republic of Bangladesh should tackle the present critical situation very carefully considering those critical risks to save our country Bangladesh.

\section{Historical Overview}

The Rohingya people are a stateless Indo-Aryan ethnic group who reside in Rakhine state, Myanmar. There was an estimated 1 million Rohingya living in Myanmar before 2016-17 crises. By December 2017, an estimated 7, 00,000 refugees from Rakhine, Myanmar ,had crossed the border into Bangladesh since August 2017.The majority are Muslim while a minority are Hindu. The atrocities committed by Burmese security forces, including mass killings, sexual violence and widespread arson, amount to crimes against humanity.

\section{Logical View of the Study}

Rohingya crisis is a great problem now days for Bangladesh .Actually it is not a new problem for Bangladesh. Before 2017 about 3, 00,000. Rohingya refugees entered in Bangladesh and most of them got Bangladeshi nationality. However, I think, recent overflow of 7, 00,000. Rohingya is also a big problem for Bangladesh, along Cox's Bazar. Local people are become sufferer for the recent Rohingya entrance. For that I felt very interest to do a research about Rohingya refugee. I am a local people of Cox's bazar and a student of sociology, that's why considering the consequence, I choose the research problem 'Emergence of Rohingya Refugee: present situation and future impact on local people of cox's bazar'.

\section{Objectives of the study}

The study attempts to address the following key research objectives.

1. To know present situation,

2. To study future impact of Rohingya refugee of Cox's bazar that includes,

- Social problem

- Political problems

- Security challenges

\section{METHODOLOGY}

This study was both descriptive and exploratory research. Teknaf and Ukhia of Cox's Bazar district were selected for the present study. The duration of the study was Six Months. 80 local peoples were purposively selected from Teknaf and Ukhia Upazila of Cox's Bazar from the total populations. Based on the objectives of the study an interview schedule and case study has done accordingly. Study data collected from both primary and secondary source. And the data collected from the survey were compiled, classified and analyzed statistically and finally presented in tabular form and figures.

\section{Theoretical Discussion}

In 1969 EVEREET S.LEE put a theory in his book A THEORY OF MIGRATION. This is called Lee's push pull theory. He begins his formulations with certain factors, which lead to spatial mobility of population. These factors are, 
- Factors associated with the place of origin,

- Factors associated with the place of destination Intervening obstacles and

- Personal factors

According to lee, each place possesses a set of positive and negative factors. While positive factors are the circumstances that act to hold people within it. Or attract people from other areas. Negative factors tend to repeal them. In addition to these, there are factors which remain neutral and to which people are essentially indifferent. While some of these factors affect most of the people in the area, others tend to have differential effects. Migration in any area is the net result of the interplay between these factors.

Lee suggests that individuals involved in migration have near perfect assessment of factors in the place of origin due to their long association. However the same is not necessarily true for that of the area of destination. There is always some element of ignorance and uncertainty with regard to reception of migrants in the new area.

Another important point is that the perceived difference between the areas of origin and destination is related to the stage of the lifecycle of an individual .A long association of an individual with a place may result in an over evaluation of positive factors and under evaluation of negative factors in the area of origin the same time, the perceived difficulties may lead to an inaccurate evaluation of positive and negative factors in the area of destination.

The final decision to move does not depend merely upon the balance of positive and negative factors at the place of origin and destination. The balance in favor of the move must be enough to overcome the natural inertia and intervening obstacles .Distance separating the places of origin and destination has been more frequently referred to in this context by authors, but according to lee distance while omnipresent, is by no means the most important factors. Furthermore, the effect of this intervening obstacle varies from individual to individual.

Apart from the factors associated with the places of origin and destination and the intervening obstacles, there are many personal factors, which promote or retard migration in any area .Some of these are more or less constant throughout the life span of an individual, while others tend to vary in effect with the stages in life cycle.It may be noted that the real situation prevailing at the places of origin and destination are not as important in affecting migration as individuals perception of these factors. The process of perception depends, to a large context. On the personal factors like awareness, intelligence, contacts, and the cultural milieu of the individual.

The decision to migration is the net result of the interplay among all these factors. Lee pointed out that the decision to migrate is, however never completely rational. Also important to note here is the fact that not all persons who migrate do so on their own decision. Children and wives move with the family where their decisions are not necessarily involved. After outlining the factors at origin and destination, and the intervening obstacles and personal factors, lee move on to formulate a set of hypothesis's concerning the volume of migration. Streams, and counter streams, and the characteristics of migrants.

This theory is appropriate for the migration of Rohingya refugee. They aremigrated to Bangladesh because of political oppression of Myanmar government

\section{Result of the Present Study}

Table 1. Age of Respondents

\begin{tabular}{ccc}
\hline Age & Frequency & Percentage \\
\hline $21-25$ & 15 & 12.5 \\
$26-30$ & 23 & 19.17 \\
\hline
\end{tabular}




\begin{tabular}{ccc}
\hline $31-35$ & 41 & 34.17 \\
$36-40$ & 13 & 10.83 \\
$40-50$ & 28 & 23.33 \\
\hline Total & $\mathbf{1 2 0}$ & $\mathbf{1 0 0}$ \\
\hline
\end{tabular}

Source: Data collected from Field, 2019

After analyzing data we find that, $12.5 \%$ of respondents are between 21 to 25 years aged, $19.17 \%$ of respondents are 26 to 30 years aged, $34.17 \%$ of respondents are 31 to 35 years aged, $10.83 \%$ of respondents are 36 to 40 years aged and $23.33 \%$ of respondents are more than $40-50$ years.

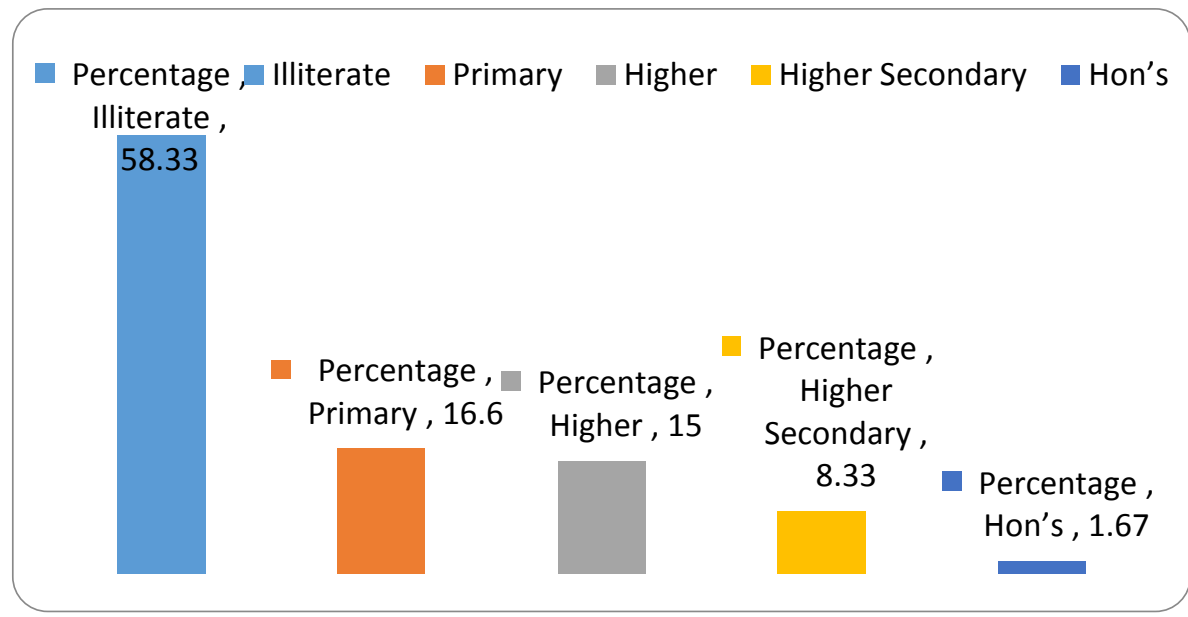

Source: Data collected from Field, 2019

Figure 1. Educational Qualification

From data analysis we can say that, per 70 person or $58.33 \%$ respondents are illiterate, per 20 person or $16.67 \%$ respondent are completed primary level of education, per 18 person or $15 \%$ respondents are completed higher level of education, per 10 person or $8.33 \%$ respondents are completed higher secondary level of education and per 2 person or $1.67 \%$ respondents are completed hon's level.

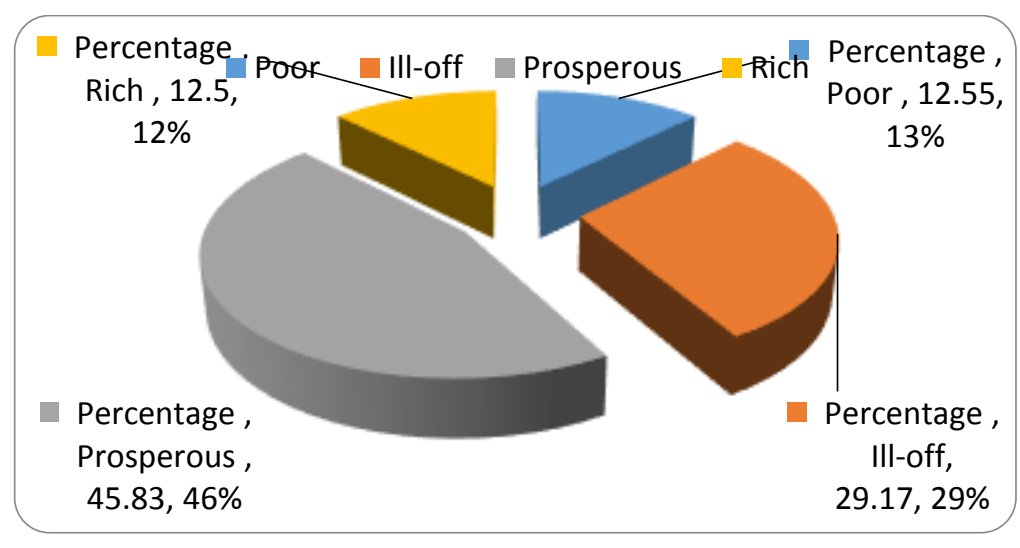

Source: Data collected from Field, 2019

Figure 2. Economic Condition

By analysis of data we find that, per 15 people or $12.55 \%$ respondents are poor, per 35 people or $29.17 \%$ respondents are ill-off, per 55 people or $45.83 \%$ respondents are prosperous, per 15 person or $12.5 \%$ respondents are rich. 


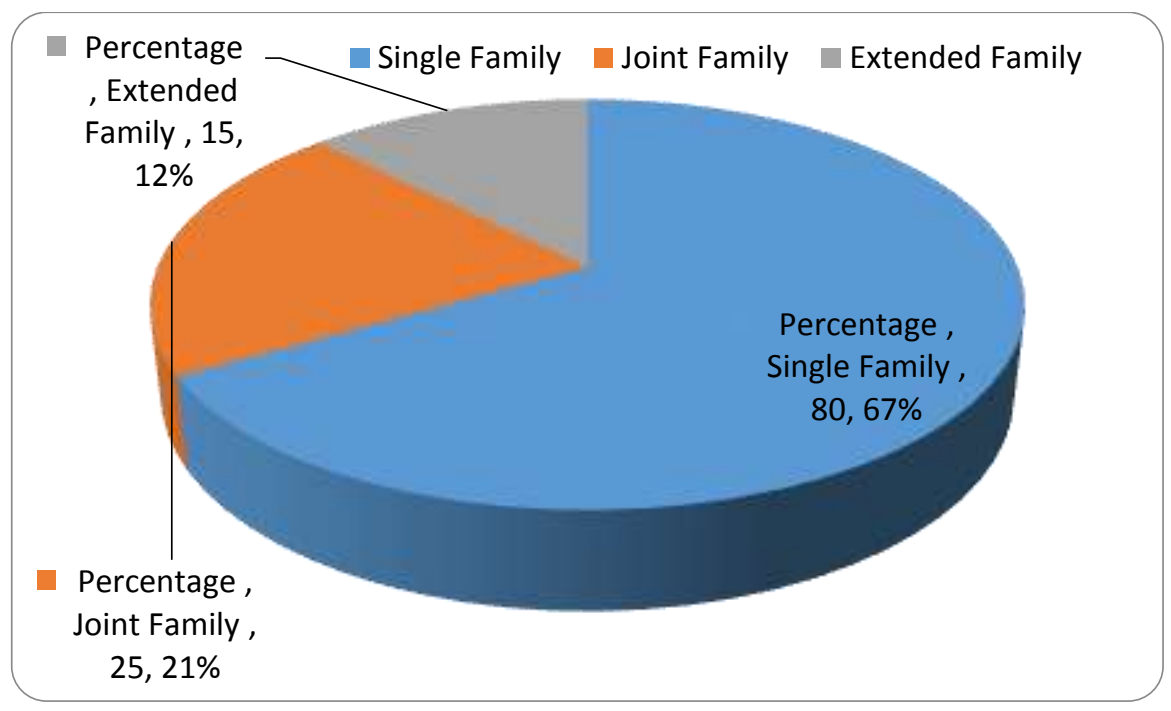

Source: Data collected from Field, 2019

Figure 3. Family Formats

By data analysis we find that, per 80 person respondents belong to single family, per 25 people of respondents belong to joint family, per 15 person respondents belong to extended family.

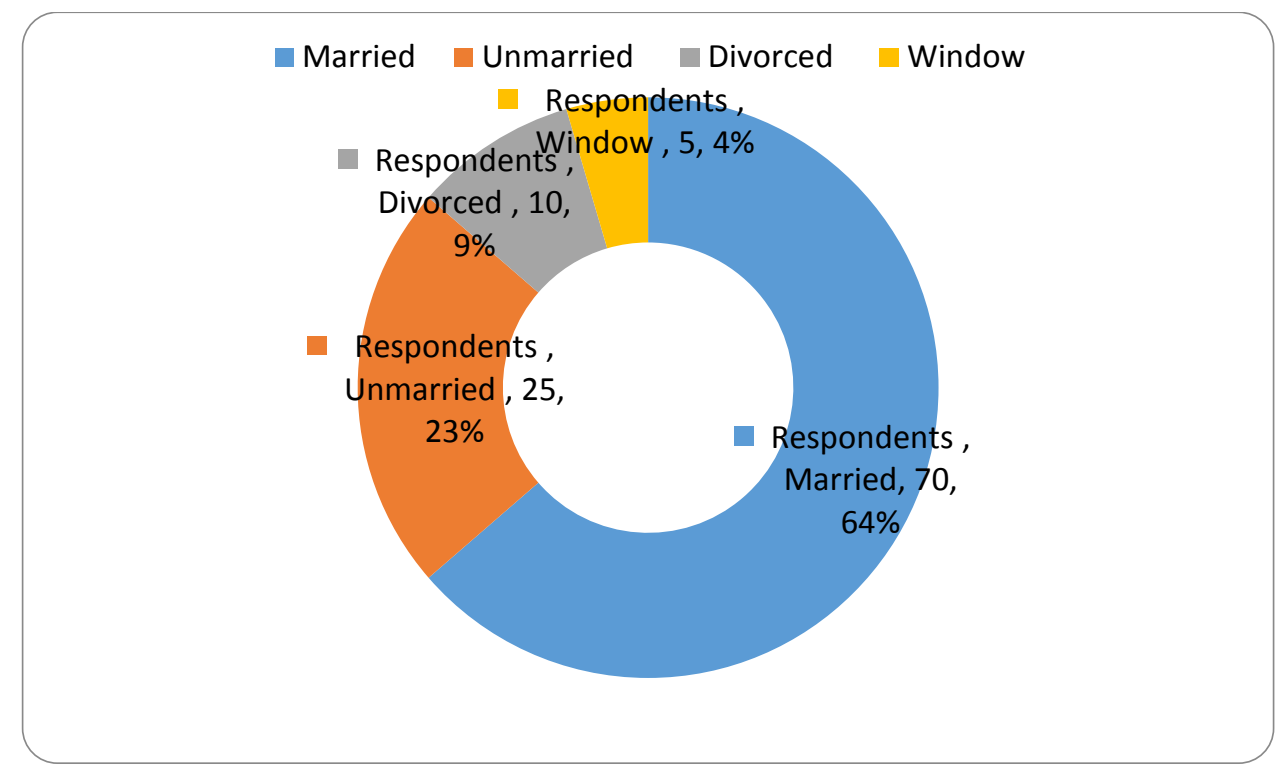

Source: Data collected from Field, 2019

Figure 4. Marital Status

From data analysis we find that, per 70 person respondents are married, per 25 person respondent are unmarried, per 10 person respondent are divorced and per 5 person respondent are widow.

Table 2. Sex of Respondent

\begin{tabular}{lcc}
\hline Sex & Frequency & Percentage \\
\hline Male & 72 & $60 \%$ \\
Female & 48 & $40 \%$ \\
Total & $\mathbf{1 2 0}$ & $\mathbf{1 0 0 \%}$ \\
\hline
\end{tabular}

Source: Data collected from Field, 2019 
From the table we see that, per 72 persons or $60 \%$ respondents are male and 48 person or $40 \%$ respondents are female respondents.

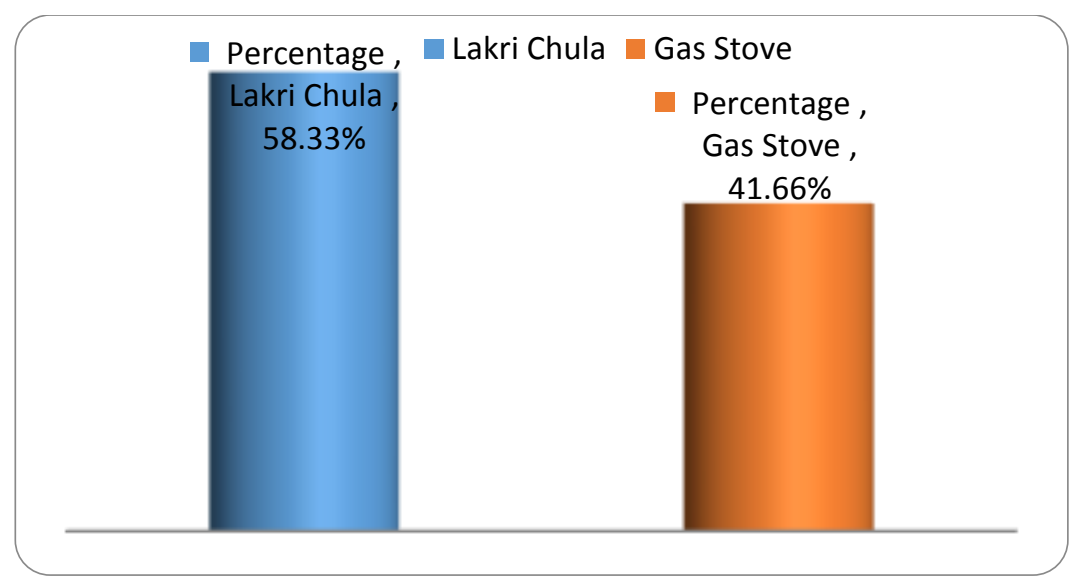

Source: Data collected from Field, 2019

Figure 5. Fuel System

From the figure we find that, per 70 families or $58.88 \%$ respondent use traditional Lakri Chula, per 50 families or $41.66 \%$ respondent use gas stove.

Table 3. House Format

\begin{tabular}{lcc}
\hline House Format & Frequency & Percentage \\
\hline Mud House & 10 & $8.33 \%$ \\
Fence House & 95 & $79.17 \%$ \\
Semi Brick Built House & 15 & $12.5 \%$ \\
Total & $\mathbf{1 2 0}$ & $\mathbf{1 0 0 \%}$ \\
\hline
\end{tabular}

Source: Data collected from Field, 2019

Above the table we find that, per 10 people or $8.33 \%$ respondents belong mud house, per 95 people or $79.17 \%$ respondents belong fence house, per 15 person or $12.5 \%$ belong semi brick built house.

Table 4. Sources of Water

\begin{tabular}{lcc}
\hline Sources of Water & Frequency & Percentage \\
\hline NGO Provided Tube-well & 98 & $81.66 \%$ \\
Hill Rhyme & 22 & $18.33 \%$ \\
Total & $\mathbf{1 2 0}$ & $\mathbf{1 0 0 . 0 0 \%}$ \\
\hline
\end{tabular}

Source: Data collected from Field, 2019

Above the table we can say that per 98 person or $81.66 \%$ respondents use NGO provided tube-well and per 22 person or $18.33 \%$ respondents use Hill Rhyme.

Table 5. Families who have Relatives in Outside the Country

\begin{tabular}{lcc}
\hline Country & Frequency & Percentage \\
\hline Saudi Arabia & 50 & $33.33 \%$ \\
Malaysia & 30 & $25 \%$ \\
Australia & 03 & $2.5 \%$ \\
Thailand & 37 & $30.83 \%$ \\
Total & $\mathbf{1 2 0}$ & $\mathbf{1 0 0 . 0 0 \%}$ \\
\hline Source: Data collected from Field, 2019 &
\end{tabular}

From the table we can say that the respondents have at least one relative who live in outside the country. Here per 50 person or $33.33 \%$ respondents have relatives in Saudi 
Arabia, per 30 people or $25 \%$ respondents have relatives in Malaysia, per 3 person or $2.5 \%$ respondents have relatives in Australia, per 37 person or $30.83 \%$ respondents have relatives in Thailand.

Table 6. Use of Electronic Device

\begin{tabular}{lcc}
\hline Device Name & Frequency & Percentage \\
\hline Mobile Phone & 85 & $70.83 \%$ \\
Radio & 10 & $8.33 \%$ \\
Solar Fan & 20 & $16.66 \%$ \\
Laptop & 05 & $4.16 \%$ \\
Total & $\mathbf{1 2 0}$ & $\mathbf{1 0 0 . 0 0 \%}$ \\
\hline
\end{tabular}

Source: Data collected from Field, 2019

Above the Table we find that per 85 person or $70.83 \%$ respondents belong mobile phone, per 10 people or $8.33 \%$ respondents use radio, per 20 person or $16.66 \%$ respondents use solar fan, per 5 people or $4.16 \%$ respondents use laptop.

\section{DISCUSSION AND FINDINGS}

'How the Rohingya crisis is affecting Bangladesh and why it matters ' is a big question. Entire world praises Bangladesh for playing host to over a million persecuted Rohingy as from Myanmar. But with its huge population and limited resources, Bangladesh's capability to accommodate more has now been put into a test. With each passing days as more and more Rohingyas are being made to leave India and Saudi Arabia, Bangladesh now has to accept more refugees than this country ever thought of hosting.

Over the last few months, around 1300 Rohingya Refugees have crossed the Bangladesh India border into the country and taken shelter in the camps in Cox's bazar. The Saudi Government is also deporting Rohingyas holding Bangladeshi passports.

From India,the refugees are crossing the border with the aid of traffickers. Many say they had been living in Jammu- Kashmir, new Delhi, Assam, Hyderabad, and many other areas for five or six years. A group of Rohingyas, including 17 children and six women, were moored for five days in the no-man's land outside Brahmanbaria for from Friday evening, attempting to enter Bangladesh. Similarly the Saudi Arabia has recently departing Rohingya refugees to Bangladesh, accusing them of holding Bangladeshi passport illegally.

For decades, Rohingyas fleeing persecution have taken shelter in the neighboring countries. It is estimated that there are at least 40000 Rohingyas in India. In the last few months, many of them have been deported to Myanmar, and many others detained.

Rohingyas living in the camps said many of their friends and family had made their way into UAE, Indonesia, Pakistan, Australia, Malaysia, Canada and other countries with Bangladeshi passports. They also say if they are deported they want to come back to Bangladesh as Myanmar is not safe for them yet.

Rohingya refugees sheltered at the Kutupalong Transit Camp in Cox's bazar said they were doing alright at the refugee camps in India .But they have escaped to Bangladesh since the Indian government began forcefully deporting the refugees the Myanmar .Every week a Rohingya family or two is crossing the border into Bangladesh. Most of them are getting back together with family members who are already in the refugee camps here. The refugees are coming into the country by engaging traffickers at the India Bangladesh border.

Rabeya Khatun name of one respondent who also came from India and was put in Kutupalongcamp. She said 'the seven of us came through the Monipur border, paying 10000 per person. My husband and children came through another route. Then we met up and came to this camp. 
Mia Hossain, 60, said he and his family did not want to go to their homeland in Myanmar's Rakhine until the situation there was calm and safe.

Let us stay here in this Rohingya camp our relative's area all here. We can stay here. I urge the international community to prevent the Indian government from deporting Rohingyas to Myanmar.' He added.

It is said that Myanmar is violating the Rohingya's humanitarian right. By respondent it is found that between 30 to 40 ages people are totally illiterate. There are some primary educational institutions in camp. But they told that they do not give them any certificate and for that it is totally useless.

Some do study going to the local school but in that case they have to hide their identity. They have no opportunity to get higher education. So they are very depressed.

According to their formation of family it is noticed that most of the Rohingya family is single .There also I notice that combined family is decreasing day by day. One of the cause is they are given very small house to live. So they prefer small family unit. A family consist of 5 members is given 10 feet space only. So it is very hard to stay combined in camp.

Another point is that among respondent most of them were married. They get married very early at age. The girls are got married at 13 to 14 ages. The boys are most of them got married at 19 to 20 years.

Among respondents most of the family owns immigrant person in different countries. And most of them have enough money to lead a prosperous life.

In research we found that Rohingya families have gas stove and it is provide by different organizations. They collect drinking water from nearest tube-well .Because of the huge quantity of refugee the tube-well is not enough for them, they urged. Those who have ability they own tube-well in their house by own cost. But it is very rare.

Some Rohingya people go to overseas such as Malaysia, Thailand etc. And those who become able to make Bangladeshi passport they go to Australia, Saudi Arabia etc. Most of them go to Malaysia.

Most of the Rohingya people use android mobile phone. They buy sim card by local shopkeeper and people. They have laptop users also.

In camp there is working many NGOs by different issues. But they do not teach about family planning. And they do not use any birth control. So that the population is growing day by day rapidly. They are very conservative also.

They are getting various training such as CTA (Community Technology Access) teach how to make soup and there is a vocational training center also. They learn about computer from CTA .Some women learn about tailoring also and it is very effective.

Unfortunately there is no electricity. So they use solar light for their use. Some also use traditional lighter which is used by oil. Another point is many Rohingya do work as shopkeeper. They have no permission to do work outside the camp. So they work inside the camp. Rohingya who are little literate they do job at different NGOs. And who are totally illiterate do work as daily worker. When we ask them about their given facilities, they told us that it is not enough for them, so authorities should increase the facilities. And they also urged for higher education for them.

At last they told that they want to go back to their homeland. But they disagree to move to another place like Subornochor, Thengarchor etc. As cause they showed that this chor is not appropriate for living.

\section{CONCLUSION}

As the world continues to deal with large-scale population movements across borders, Much deeper, context-specific research on political, economic, social, security and environmental 
impacts is crucial to help neighboring countries manage protracted crises in humane and sustainable ways. The circumstances in Myanmar are snowballing enormously into a major humanitarian crisis, and have begun to have ripple effects over the region in terms of rebirth of transitional crimes, insecure state borders, social impacts on hosting countries religious, ethnic and cultural balance etc. Despite international provisions, treaties, global conventions and other diplomatic measures to prevent the occurrence of atrocities, crimes and fiercely actions on civilians, violence against Rohingya Muslims in Myanmar continues unabated.

In case of Myanmar, strengthening and rebuilding its commitment to democratic ideals, human rights and Rule of Law, should not be under limitation of just providing immediate security and relief to the suffering Rohingyas, as it is the bare minimum possible i feel. It must include a long-term, permanent and accountable stratagem that helps integrate the Rohingyas and other minorities; recognizing their sacrifices and contributions to the country thus creating spaces for every person, without discrimination and giving full expression of speech to his or her potential, free from any fear, resultantly leading the peace and tranquility to prevail around the globe.

\section{Experiences of fieldwork and Limitations:}

I have gathered a lot of positive experiences during completing my research. The respondents were mentally very strong and though I am a local of Cox's bazar so I do not face serious problems to connect with them. They participated very cordially during my survey. This was very helpful for me.

When I went to field to data collection the Rohingya people thought me as a NGO worker, but at last told them about my purpose so that they can understand my situation. They expected money or other beneficiaries also. Then I ensured them, I $\mathrm{m}$ a student of university of Chittagong and this is very helpful to doing my research successfully completed.

\section{REFERENCES}

Ahmed, I. (Ed.). (2010). The plight of the stateless Rohingyas: Responses of the state, society \& the international community. University Press Ltd, Dhaka, Bangladesh.

Alam, K. (2017). Myanmars Rohingya Crisis: An Analysis of Security Threats of South Asia. International Journal of Multidisciplinary Educational Research, 6, no.3

Aljazeera. (2018). Myanmar, Who are the Rohingya. Available from: https://www.aljazeera.com/indepth/features/2017/08/rohingya-muslims 170831065142812.html.

Anand, J. (1978). Bangladesh-Refugees from Burma. Economic and Political weekly. Available from: https://www.epw.in/author/j-p-anand

Available from: https://www.thedailystar.net/rohingya-crisis/news/bangladesh-wants-saferepatriation-rohingyas-1709101

Barry, B. (1975). Political Accommodation and Convocational Democracy. British Journal of Political Science. 5(4):477-505.

Boynton G, Kwon W. (1978). An Analysis of Convocational Democracy. Legislative Studies Quarterly. 11-25

Chowdhury, M. (2006). The advent of Islam in Arakan and the Rohingyas. Available from: http://www.rohingya.org/portal/index.php/rohingya-library/26-rohingya-history/83-theadventof-islam-in-arakan-and-the-rohingyas.pdf

Cox's Bazar News (2019). Three Hundred ninety People are Infected with AIDS Cox's Bazar, Bangladesh.

Hasan, K. (2018). Experts: Rohingya Crisis Could Turn into a Long-Term Problem: Available from: Dhaka Tribune. https://reliefweb.int/report/bangladesh/iom-bangladeshappeal-rohingya-humanitarian-crisis-response-january-december-2019 
https://www.coxsbazarnews.com/archives/183676.html?fbclid=IwAR0aeen

https://www.dhakatribune.com/bangladesh/2018/09/02/experts- rohingya-crisis-could-turninto-a-long-term-problem.

https://www.thedailystar.net/rohingya-crisis/news/crimes-against-rohingya-myanmar-notserious-about-probe-hrw-1676755

International Organization for Migration. (2019). Bangladesh appeal: Rohingya humanitarian crisis response.

Jawad, F. (2015). The Rohingya Crisis: Implications and Recommendations. Searched on March 2, 2019. Available from:http://stratagem.pk/geostrategy/the-rohingya-crisisimplications-and-recommendations

Kevin, K. (2012). Norman Schwarzkopf: 10 Quotes on Leadership and War. Forbes. Searched on February 23, 2019. Available from: https://www.forbes.com/sites/kevinkruse/2012/12/27/norman-schwarzkopf-quotes /\#8ee44af4eebc

Kipgen, N. (2012). Conundrum of the Rohingyas. Jerusalem Post. Available from: https://www.jpost.com/Opinion/Op-Ed-Contributors/Conundrum-of-the-Rohingyas.

Kipgen, N. (2014). Addressing the Rohingya problem. Journal of Asian and African Studies. 49(2):234-47.

Kipgen, N. (2015). Democratisation of Myanmar: Routledge India. Available from: https://www.taylorfrancis.com/books/9781317312130miYieBW83wtnnnVu1RQ_VSNp berETSjBzypR2SH7e4kxt9PDDpiA.

Parnini, S. (2013). The Crisis of the Rohigya as a Muslim Minority in Myanmar and bilateral relations with Bangladesh. Journal of Muslim minority affairs, vol.33, pp, 281-297.

Ragland, TK. (1994). Burma's Rohingyas in Crisis: Protection on Humanitarian Refugees under International Law. Boston college third world law journal. 14:301.

Ranjan, A. (2017). The Rohingya Crisis- A challenge for India and Bangladesh. Institute of South Asian Studies, National University of Singapore, 6, pp, 1-19.

Siddiquee, M. M. (2012). Who are Rohingyas and How? Origin and evelopment of the Rohingyas in Arakan. To Host or To Hurt. Counter-narratives on Rohingya Refugee Issue in Bangladesh. ICDY: Institute of Culture \& Development Research: Bangladesh, 15-28.

The Daily Star (2018). Rohingya crisis: Crimes against Rohingya : Myanmar not serious about probe: HRW. Available from: The Daily Star (2019). Rohingya crisis: Won't take any more Rohingyas.

Uddin, K, \&Ahamed, A. (2008). Bangladesh Myanmar Relations: Continuity and change. The Chittagong university journal of social sciences vol26, $\mathrm{p}$ (79-98).

Uddin, N. (Ed.). (2012). To host or to hurt: Counter-narratives on Rohingya refugee issue in Bangladesh. Institute of Culture and Development Research. 10(1), 31-52.

United Nations Refugee Agency. (2017). Rohingya emergency. Available from: https://www.unhcr.org/rohingya-emergency.html.

World Food Program. (2018). Rohingya Crisis: A Firsthand Look Into The World's Largest Refugee Camp. Available from: https://www.wfpusa.org/articles/a-firsthand-look-intothe-worlds-largest-refugee-camp/.

Yesmin, S. (2016). Policy Towards Rohingya Refugees: A Comparative Analysis of Bangladesh, Malaysia and Thailand. Journal of the Asiatic Society of Bangladesh (Hum.), vol.61 (1), pp, 71-100. 